\title{
University of New Hampshire
}

Carsey School of Public Policy

\section{CARSEY RESEARCH}

National Fact Sheet \#38

Spring 2018

\section{Domestic Migration and Fewer Births Reshaping America}

Kenneth M. Johnson

$\mathrm{N}$ ew Census Bureau data released on March 22, 2018, demonstrate the continuing influence of domestic migration on U.S. demographic trends. Migration patterns are reverting to those common before the recession. Suburban counties of large metropolitan areas, smaller metropolitan areas, and rural counties proximate to metropolitan areas all gained more domestic migrants in the last year. In contrast, domestic migration losses grew in the core counties of metropolitan areas of 1 million or more and remained substantial in rural counties that are not adjacent to an urban area.

\section{FIGURE 1. DOMESTIC MIGRATION BY METROPOLITAN} STATUS, 2015 TO 2017

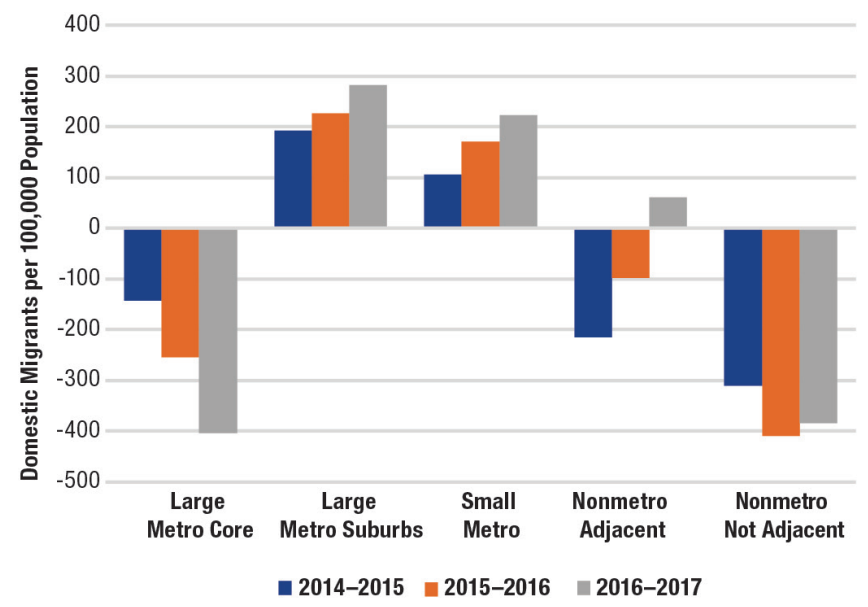

Source: U.S. Census Bureau Estimates

\section{KEY FINDINGS \\ (7) Domestic migration losses from large urban cores rose sharply. \\ Domestic migration gains are accelerating in other metro areas. \\ S3 : Population growth has resumed in rural areas. \\ ใับ More people are dying, but births remain low.}

\section{Migration Losses Mounting in Large Metro Cores, as Suburban Gains Are Accelerating}

Domestic migration is the movement of people from one U.S. county to another. Between July of 2016 and July of 2017, there was a net domestic migration loss of 398,000 from the urban core counties of metro areas of 1 million or more, where nearly 100.2 million people reside. Migration loss reduced the population gain in these urban cores by 18 percent to 728,000 last year. Such accelerating domestic migration losses diminished population gains from immigration and the surplus of births over deaths. This loss of 404 domestic migrants per 100,000 residents is more than double the rate just two years ago (Figure 1). It signals a return to migration losses similar to those large urban cores suffered prior to the Great Recession.

In contrast, population gains are increasing in the suburban counties of these large urban areas because of growing domestic migration. The population grew by 802,000 from July 2016 to July 2017 in the suburban counties of these large metropolitan areas to 80.7 million. 
A domestic migration gain of 224,000 supplemented gains from immigration and natural increase here. The population gain in these suburban counties exceeded that in the urban cores for the first time since 2010, even though these suburban counties contain nearly 20 million fewer people.

Growth also accelerated in smaller metropolitan areas of less than a million that contained 98.7 million people in 2017. The rate of domestic migration gain nearly doubled here in the past two years from 107 per 100,000 residents to more than 222 , producing a net domestic migration gain of 217,000 last year.

\section{Rural America Growing Again Due to Domestic Migration Gains in Some Areas}

For the past several years, rural America experienced overall population loss for the first time in history. Last year, overall growth resumed in nonmetropolitan America where 46.0 million people reside in 1,976 counties. This population gain was small, just 33,000 (.1 percent), but it contrasts with a loss of 47,000 two years ago. The gain was fueled by renewed domestic in-migration to rural counties near metropolitan areas. Historically, these rural counties grew faster than more remote rural counties because metropolitan sprawl spilled over into them. The Great Recession reversed this long-term trend and for several years adjacent counties lost more population than remote rural counties. Between July of 2016 and July of 2017, adjacent rural counties gained 57,000 residents because a domestic migration gain supplemented immigration and natural increase. In contrast, rural counties that were not near metropolitan areas continued to lose population due to sustained domestic migration loss.

Growth rates vary widely across rural America. The fastest growing rural counties have recreational and scenic amenities and many also appeal to retirees. Such counties have traditionally attracted domestic migrants, but such migration sharply diminished during the Great Recession. Migrants are again coming to these recreational and retirement areas. The domestic migration gain here last year was three times as large as it was three years ago.

Rural farm counties continued to experience domestic outmigration and population loss last year, but the loss was less than in previous years. During the recession, rural manufacturing counties lost population because of a significant domestic migration loss. Last year, rural manufacturing counties experienced a small population gain, in part because domestic migration loss diminished.

\section{Fewer Births, Record High Deaths}

Between July 2016 and July 2017, there was a record number of deaths $(2,746,000)$ and relatively few births $(3,978,000)$. The excess of births over deaths $(1,232,000)$ is the lowest in 35 years. Even though there are more women of prime child bearing age now than ten years ago, births dropped by 8.4 percent from a record 4,316,000 in 20062007 during the economic boom. There is no evidence of any recovery from this fertility decline in the new data. Recent National Center for Health Statistics data show that fertility rates remain near record lows. Nearly 600,000 fewer babies were born last year than would have been the case had the fertility rates just before the recession been sustained. ${ }^{1}$ Young women, in particular, are having fewer babies. And, 2.1 million fewer women between the ages of 20 and 39 have had their first child than would have been expected given pre-recession fertility patterns. ${ }^{2}$ It is not yet clear whether these births are being delayed or whether they will be foregone.

With fewer births and record deaths, there were insufficient births to offset deaths in 1,200 counties (38.7 percent). Natural decrease (more deaths than births) is occurring in 45 percent of the nation's rural counties and 24 percent of urban counties. This year, deaths exceeded births in two entire states: more people died than were born in both Maine and West Virginia.

\section{End not es}

1. See Kenneth M. Johnson, "New Data Show U.S. Birth Rates Hit Record Lows," Data Snapshot (Durham, NH: Carsey School of Public Policy, University of New Hampshire, June 30, 2017).

2. See Kenneth M. Johnson, "2.1 Million More Childless U.S. Women Than Anticipated," Data Snapshot (Durham, NH: Carsey School of Public Policy, University of New Hampshire, December 12, 2017).

\section{About the Author}

Kenneth M. Johnson is senior demographer at the Carsey School of Public Policy, professor of sociology at the University of New Hampshire and an Andrew Carnegie Fellow (ken.johnson@unh.edu).

\section{A cknowledgments}

This research was funded by Dr. Johnson's Andrew Carnegie Fellowship from the Carnegie Corporation of New York and by the New Hampshire Agricultural Experiment Station. 